\title{
CONSIDERAÇÕES SOBRE A SISTEMÁTICA DE PRECEDENTES JUDICIAIS DO CPC DE 2015'
}

\section{CONSIDERATIONS ON THE SYSTEM OF JUDICIAL PRECEDENTS OF THE 2015} CODE OF CIVIL PROCEDURE

Alvaro de Azevedo Gonzaga

Livre Docente em Filosofia do Direito pela PUC-SP. PósDoutorados na Faculdade de Direito da Universidade Clássica de Lisboa e na Universidade de Coimbra. Doutor, Mestre e graduado em Direito pela PUC-SP. Graduado em Filosofia pela Universidade de São Paulo - USP. Professor concursado da Faculdade de Direito da PUC-SP, tanto na Graduação como na Pós-Graduação Stricto Sensu. Membro do Instituto Euro-Americano de Derecho Constitucional, na Condição de Membro Internacional. Ex-presidente do Instituto de Pesquisa, Formação e Difusão em Políticas Públicas e Sociais. Coordenador do Escritório Modelo da PUC-SP. São Paulo - SP, Brasil. E-mail: algonzaga@pucsp.br

Felipe Labruna Mestrando e graduado em Direito pela Pontifícia Universidade Católica de São Paulo (PUC-SP). Especialista em Ciência Política pela Fundação Escola de Sociologia e Política de São Paulo (FESPSP) e em Direito Processual Civil pela Escola Paulista da Magistratura (EPM). Oficial da Reserva do Exército Brasileiro pelo Centro de Preparação de Oficiais da Reserva do Estado de São Paulo (CPOR-SP). Servidor do Tribunal de Justiça do Estado de

\footnotetext{
${ }^{1}$ Artigo recebido em 26/08/2020 e aprovado em 06/01/2021.
} 
Revista Eletrônica de Direito Processual - REDP.

Rio de Janeiro. Ano 15. Volume 22. Número 2. Maio a Agosto de 2021

Periódico Quadrimestral da Pós-Graduação Stricto Sensu em Direito Processual da UERJ

Patrono: José Carlos Barbosa Moreira (in mem.). ISSN 1982-7636. pp. 22-44

www.redp.uerj.br

São Paulo (TJ-SP). São Paulo - SP, Brasil. E-mail:

fe.labruna@gmail.com

Jéssyca Verucy R. Barbosa

Mestranda em Direito pela Pontifícia Universidade

Católica de São Paulo (PUC-SP). Especialista em Direito

Tributário pelo Instituto Brasileiro de Estudos Tributários

(IBET). Graduada em Direito pela Universidade Regional

do Cariri (URCA-CE). Advogada. São Paulo - SP, Brasil.

E-mail: jessycaverucy@ hotmail.com

RESUMO: O presente artigo tem por finalidade analisar a aplicação do sistema de precedentes como uma das formas de uniformização da jurisprudência, o que viabiliza tanto a efetividade quanto, e principalmente, a segurança jurídica. Os artigos 926 a 928 do Código de Processo Civil 2015 foram essenciais para a diminuição da grande demanda de processos nos Tribunais e da diversidade de entendimentos para casos semelhantes, o que gerava incerteza e ineficiência do Poder Judiciário, uma vez que a variedade de posicionamentos sobre situações análogas custava muito tempo, postergando assim, para um futuro incerto a promoção da Justiça. O sistema de precedentes previsto no CPC de 2015 mostra-se efetivo por promover a certeza do Direito e a isonomia.

PALAVRAS-CHAVE: Precedentes. Segurança Jurídica. Uniformidade jurisprudencial. Efeitos Vinculantes. Isonomia

ABSTRACT: The present article aims to analyze the application of precedents as one of the forms of standardization of jurisprudence, which enables both effectiveness and, especially, legal certainty. Articles 926 to 928 of the new Code of Civil Procedure were essential and necessary to reduce the great demand for lawsuits in the Courts and the diversity of understandings for similar cases, which generated uncertainty and ineffectiveness of the judiciary, since the diversity of understandings about the same case cost a lot of time, thus postponing the promotion of justice for an uncertain future. The system of precedents 
Revista Eletrônica de Direito Processual - REDP.

Rio de Janeiro. Ano 15. Volume 22. Número 2. Maio a Agosto de 2021

Periódico Quadrimestral da Pós-Graduação Stricto Sensu em Direito Processual da UERJ

Patrono: José Carlos Barbosa Moreira (in mem.). ISSN 1982-7636. pp. 22-44

www.redp.uerj.br

foreseen in the 2015 Code of Civil Procedure is effective in promoting the certainty of the Law and isonomy.

KEYWORDS: Precedents. Legal Security. Jurisprudential uniformity. Binding Effect. Isonomy

\section{Introdução}

A história do direito brasileiro está ligada ao direito português que, por sua vez, está ligado a essencialmente todo o direito do Ocidente. O Código de Processo Civil de 1939 representou passo crucial a fim de que nosso direito processual a adentrasse a esfera científica do processo. Conjuntamente à continuidade histórica da base do direito brasileiro desde as Ordenações portuguesas, o CPC de 1939 acompanhava as vertentes teóricas de Giuseppe Chiovenda, Franz Klein e José Alberto dos Reis, estudiosos que tiveram grande relevância para o aprimoramento do direito processual, respectivamente, na Itália, Áustria e Portugal. ${ }^{2}$ Entre os principais atributos do CPC de 1939 estava a aplicação do princípio da oralidade tal como alvitrou Chiovenda, com determinadas condescendências à tradição, principalmente no que se refere aos instrumentos recursais e à propagação de procedimentos próprios. Em virtudes de duras críticas efetuadas pelos estudiosos e tendo surgido diversas leis especiais, foi preciso a reestruturação do CPC de 1939, o que originou o Código de Processo Civil de $1973 .^{3}$

Em relação ao seu antecessor, o Código de Processo Civil de 1973 não demonstrou grandes modificações. Os predicamentos essenciais mantiveram a mesma sistemática e o processo de conhecimento em si não sofreu modificações em sua estrutura. Assim sendo, o CPC de 1973 não refletiu uma revolução frente ao Código procedimental anterior, afinal ratificava o mesmo modelo processual de outrora, exibindo apenas uma estética com melhor aspecto no que diz respeito a alguns institutos e um aprimoramento em outros. No que diz respeito à sua estrutura em si, apesar de se apresentar mais sucinto e sistemático que seu

\footnotetext{
${ }^{2}$ RAATZ, Igor e SANTANNA, Gustavo da Silva. Elementos da história do processo civil brasileiro: do Código de 1939 ao Código de 1973. Revista Justiça e História, vol. 18. Porto Alegre: 2001.

${ }^{3}$ OLIVEIRA, Celso Marcelo de. Moderno Direito Processual Civil do Brasil e de Portugal. Revista de Doutrina da $4^{a}$ Região, $\mathrm{n}^{\circ} 10,2006$.
} 
Revista Eletrônica de Direito Processual - REDP.

Rio de Janeiro. Ano 15. Volume 22. Número 2. Maio a Agosto de 2021

Periódico Quadrimestral da Pós-Graduação Stricto Sensu em Direito Processual da UERJ

Patrono: José Carlos Barbosa Moreira (in mem.). ISSN 1982-7636. pp. 22-44

www.redp.uerj.br

predecessor, o CPC de 1973 não apresentou então reflexos práticos. ${ }^{4}$ Quarenta e dois anos após a publicação do CPC de 1973, o Novo Código de Processo Civil de 2015 conservou em seu texto institutos procedimentais de processo civil que tiveram resultados positivos e introduziu outros com a finalidade de descomplicar e fornecer unidade ao sistema, possibilitando que o juiz de Direito concentre de maneira mais acentuada seu cuidado com o mérito das causas. Assim, com a finalidade de conceder rapidez aos processos judiciais civis, foram criados mecanismos para a identificação de ações que contenham os mesmos temas de direito a fim de tenham julgamentos uniformes.

Em que pese o direito brasileiro ser considerado como sistema típico do Civil Law, o novo código de Processo Civil inseriu em nosso ordenamento jurídico o modelo de precedentes semelhante àquele utilizado pelo sistema do Commom Law. Com isso, o sistema de precedentes foi inserido no nosso ordenamento de forma "caricaturada", uma vez que o Senado Federal excluiu do projeto final do $\mathrm{CPC} / 15$ os dispositivos legais que tratavam pela primeira vez em nosso sistema processual pátrio dos precedentes judiciais da mesma forma como eram tratados pelos países anglo-saxônicos. Assim, os dispositivos 926 a 928 do novo Código de Processo Civil trouxeram apenas fragmentos daquilo que seria um verdadeiro sistema de precedentes conforme os países anglo-saxônicos, pois ao vincular certos julgados dos tribunais superiores, acabou ampliando, assim, o já existente conceito de "súmula vinculante".

A uniformização de jurisprudência e a exigência de precedentes obrigatórios vieram mitigar o livre convencimento motivado do julgador para salvaguardar um valor máximo da Constituição, a segurança jurídica. Assim, diante de casos idênticos e similares, um magistrado não possui liberdade para decidir de modo contrário ao previsto em um precedente, salvo à livre apreciação da prova ou com a demonstração de que se trata de um caso que não se adequa ao precedente. A finalidade dos artigos 926 a 928 do CPC/2015 consiste em promover a certeza do Direito, corolário do princípio da segurança jurídica, ao estabilizar as decisões emitidas por um tribunal de maneira que a jurisprudência seja coerente, estável e íntegra. Assim, um tribunal que não possui um consenso firmado diante de casos semelhantes incorre em mais conflitos e acentua a desigualdade entre os litigantes.

A interpretação é fundamental para a identificação dos fatos similares ao já discutido pelo tribunal e à formação do precedente. Aplicar um precedente não exime as

\footnotetext{
${ }^{4}$ DINAMARCO, Candido Rangel. A reforma do código de processo civil. $4^{\mathrm{a}}$ ed. São Paulo: Malheiros, 2001.
} 
Revista Eletrônica de Direito Processual - REDP.

Rio de Janeiro. Ano 15. Volume 22. Número 2. Maio a Agosto de 2021

Periódico Quadrimestral da Pós-Graduação Stricto Sensu em Direito Processual da UERJ

Patrono: José Carlos Barbosa Moreira (in mem.). ISSN 1982-7636. pp. 22-44

www.redp.uerj.br

autoridades judiciárias do dever de analisarem antes se seria a solução mais coerente para o caso concreto. É preciso acuidade na aplicação do precedente, uma vez que ele não é uma norma pronta, mas um texto que deve ser interpretado diante das circunstâncias. Seguindo esse raciocínio, convém destacar a fala de Georges Abboud ${ }^{5}$ :

O que outrora era creditado à lei, agora, a crença deposita nas decisões dos Tribunais Superiores. Nesse contexto, fica evidente a importância de se compreender o conceito pós-positivista de norma, para que se possa dar às leis e às decisões dos Tribunais Superiores o real poder que elas conseguem ter, nada além. Imaginar uma lei, um precedente ou uma decisão vinculante contendo a norma pronta em si para resolver diversos casos, consiste em crença que não se tolera no pós-positivismo.

O Código de Processo Civil de 2015 trouxe grande novidade em seu microssistema, na medida em que implantou em nosso ordenamento jurídico um modelo semelhante ao utilizado no sistema do common law, por meio dos chamados precedentes judiciais. Entretanto, em que pese os países anglo-saxônicos busquem uma flexibilização da estabilidade dos procedentes, o Brasil busca exatamente o oposto, ou seja, pretende unificar e fortalecer a volátil jurisprudência de seus tribunais.

Embora o legislador processualista civil tenha tido o intuito primário de instituir os moldes aplicados pelos países utilizadores da sistemática do common law, o Senado Federal removeu da versão final os dispositivos legais que regulamentavam pela primeira vez em nosso sistema legal e processual pátrio os precedentes judiciais da forma em que são adotados pelos países anglo-saxônicos. Sendo assim, segundo ensinam nossos doutrinadores processualistas, o que se vê no Código de Processo Civil de 2015 são somente resquícios desta tentativa legislativa nos seus artigos 926 e 928, muito longe de instituírem o sistema de precedentes judiciais propriamente dito do direito anglo-saxônico, já que somente foi criado em engajamento e vinculação a certos julgados dos tribunais superiores, de forma que o conceito de "súmula vinculante" já constante no antigo regramento processual fosse ampliado.

O artigo 927 do CPC não pode ser considerado a aplicação de um precedente nos moldes britânicos, uma vez que o sistema original de precedentes britânico é criador de complexidade, ao passo que o que nosso Código de Processo Civil faz é dar origem a provimentos judiciais vinculantes que possuem como objetivo justamente a redução da

\footnotetext{
${ }^{5}$ ABBOUD, Georges. Discricionariedade administrativa e judicial: ato administrativo e decisão judicial. São Paulo: Revista dos Tribunais, 2014, p. 65
} 
Revista Eletrônica de Direito Processual - REDP.

Rio de Janeiro. Ano 15. Volume 22. Número 2. Maio a Agosto de 2021

Periódico Quadrimestral da Pós-Graduação Stricto Sensu em Direito Processual da UERJ

Patrono: José Carlos Barbosa Moreira (in mem.). ISSN 1982-7636. pp. 22-44

www.redp.uerj.br

complexidade judicial. Ao analisarmos o conceito de "precedente", perceberemos que se trata de um julgado pretérito que serve como fundamentação para um novo julgamento, ou seja, o precedente é um paradigma na resolução de casos futuros e similares. Associado ao conceito de precedente está o conceito de decisão fundamentada estabelecido no artigo 489 do novo CPC: esse dispositivo entende que qualquer decisão judicial não estará fundamentada se deixar de seguir enunciado de súmula, jurisprudência ou precedentes invocados pela parte, sem demonstrar a existência de distinção no caso em julgamento ou a superação do entendimento ou se não demonstrar que os casos sub judice não se adequam a aqueles fundamentos determinantes. Com isso, se o julgador deixar de fundamentar sua decisão pelo precedente, deverá demonstrar o distinguishing e o overruling. Desse modo, para que ocorrera ou não a aplicação do precedente é inevitável a análise do caso concreto e sua comparação com o entendimento prevalecente no Tribunal.

\section{O artigo 926 do Código de Processo Civil e a uniformização de jurisprudência}

O artigo 926 do Código de Processo Civil de 2015 busca tratar da uniformização da jurisprudência e reflete uma tendência do Codex de atribuir maior destaque à atividade jurisdicional, mencionando não só a jurisprudência, como também os precedentes, em que pese o antigo Código de Processo Civil de 1973 já regulasse a uniformização da jurisprudência em seus artigos 476 a 479.

O parágrafo $1^{\circ}$ deste dispositivo legal dispõe a respeito da atividade sumular. A edição dos enunciados de súmulas dos tribunais deve, neste sentido, acompanhar os padrões e pressupostos estabelecidos em regimento interno. Essa edição de enunciados também necessita seguir a mesma linha da jurisprudência dominante. Já o parágrafo $2^{\circ}$ deste artigo dispõe que a edição dos enunciados de súmula dos tribunais deve atentar-se não apenas aos pressupostos do regimento interno, conforme determina o parágrafo $1^{\circ}$ do mesmo artigo, mas também às circunstâncias dos precedentes que impulsionaram a sua criação. Assim, a edição os enunciados de súmula por parte dos tribunais exige também a análise e interpretação das motivações e particularidade do precedente. ${ }^{6}$

Necessário atentar ao fato de que o art. 489 do novo CPC, em seu parágrafo $1^{\circ}$, dispõe que qualquer decisão judicial não estará fundamentada se deixar de seguir enunciado

\footnotetext{
${ }^{6}$ DIDIER JÚNIOR, Fredie. Curso de Direito Processual Civil. Vol. 2. 10ª ed. Salvador: JusPodivm, 2015.
} 
Revista Eletrônica de Direito Processual - REDP.

Rio de Janeiro. Ano 15. Volume 22. Número 2. Maio a Agosto de 2021

Periódico Quadrimestral da Pós-Graduação Stricto Sensu em Direito Processual da UERJ

Patrono: José Carlos Barbosa Moreira (in mem.). ISSN 1982-7636. pp. 22-44

www.redp.uerj.br

de súmula, jurisprudência ou precedentes invocados pela parte, sem demonstrar a existência de distinção no caso em julgamento ou a superação do entendimento.

\section{O regimento interno dos tribunais}

Entende-se que o regimento interno de tribunal são reuniões de regras que buscam regular, no cerne de uma instituição judicial, a sua forma de funcionar, seu modus operandi, estando destinado àqueles que fazem parte deste conjunto. Ainda que deva ser reconhecida a autonomia de cada Poder do Estado brasileiro, esta não é processada de maneira irrestrita, já que há a inevitabilidade de serem colocados limites a eles, a fim de instituir-se o equilíbrio de relações. Desta feita, preliminarmente não deve ser encarado como invasivo ao princípio da separação dos Poderes eventual controle que um Poder exercer sobre o outro. Tal controle é tratado como sistema de freios e contrapesos, também chamado checks and balances system, verificações e equilíbrios ou métodos de compensações. Portanto, a tripartição de poderes é o meio do qual o Poder é contido pelo próprio Poder, ou seja, é uma proteção ao povo contra o despotismo e o arbítrio. ${ }^{7}$

De igual forma, a harmonia entre os Poderes pode ser verificada em primeiro lugar por meio das regras de cortesia no trato entre elas e na obediência às possibilidades e prerrogativas que todos eles têm direito de maneira mútua. De outro prisma, convém observar que nem a independência entre os órgãos do poder e nem a separação de suas funções são absolutas e irrestritas. Existe interferência, que busca o estabelecimento de um mecanismo de checks and balances, à procura do equilíbrio que é necessário para a ocasião do bem comum à coletividade e imprescindível para conter o arbítrio e o despotismo de um Poder contra o outro e principalmente contra os governados.

Por respeito aos princípios de autonomia, harmonia e autogoverno dos três Poderes, é entendimento majoritário tanto da doutrina quanto da maior parte da jurisprudência que os regimentos internos dos tribunais devem ser encarados como dispositivos legais em sentido material, embora para sua criação não tenha havido cumprimento a processo legislativo. Encaradas como verdadeiras leis materiais, a Constituição Federal estabelece precisamente as condições que devem ser obedecidas pelos tribunais na ocasião de desenvolvimento de seus respectivos regimentos internos. Assim sendo, o regimento interno necessariamente

\footnotetext{
${ }^{7}$ CHIMENTI, Ricardo Cunha. Curso de Direito Constitucional, $7^{\mathrm{a}}$ ed. São Paulo: Saraiva, 2010.
} 
Revista Eletrônica de Direito Processual - REDP.

Rio de Janeiro. Ano 15. Volume 22. Número 2. Maio a Agosto de 2021

Periódico Quadrimestral da Pós-Graduação Stricto Sensu em Direito Processual da UERJ

Patrono: José Carlos Barbosa Moreira (in mem.). ISSN 1982-7636. pp. 22-44

www.redp.uerj.br

deverá ter disposições expressas sobre sua competência e também sobre a forma em que funcionam todos os seus órgãos jurisdicionais e administrativos, de tal maneira que suas secretarias e serviços auxiliares sejam organizados. Tais leis materiais dos tribunais estabelecerão seus regimes jurídico-administrativos, inclusive no que diz respeito às suas funções processuais e administrativas. Especificamente em relação às normas processuais, os tribunais possuem a obrigação de transpô-la ao seu regimento interno, não sendo possível nenhum tipo de inovação sobre o tema. ${ }^{8}$

Embora não o seja em sentido formal, o regimento interno de tribunal é lei em sentido material. Dessa forma, os regimentos internos se situam abaixo da lei na hierarquia das fontes normativas do Direito, afinal devem dar a ela sua efetiva execução. Neste prisma, todas as vezes que a lei formal contenha norma jurídica que apresente regramentos imprecisos, vagos ou que tragam somente princípios de maneira geral, sendo que sejam trazidos os detalhes que são demandados para sua efetiva observância, cabe às leis materiais, constantes de preceito regulamentar (como é o caso dos regimentos internos), aprimorá-la com comandos novos, obtendo-se dela, dessa forma, sentidos e causas nela contidos de maneira implícita ou mesmo nuances para sua execução fidedigna. Nesta situação, o teor completo da norma superior (dispositivo legal) será determinado por norma considerada inferior (regimento ou regulamento).

No que diz respeito à organização interna dos tribunais, o seu respectivo regimento é lei material. Assim sendo, no organograma das normas jurídicas, equivale à lei o regimento interno de tribunal, de forma que a prevalência de uma ou outra depende do teor da matéria regulada, afinam ambas possuem categoria equivalente. Desta feita, em relação às matérias processuais há de prevalecer a lei e no que se refere ao funcionamento e organização dos tribunais, prevalece o seu regimento interno.

Neste diapasão, aresto do Supremo Tribunal Federal ${ }^{9}$ :

Os regimentos internos dos Tribunais, editados com base no art. 96, I, a, da Constituição Federal, consubstanciam normas primárias de idêntica categoria às leis, solucionando-se eventual antinomia não por critérios hierárquicos mas, sim, pela substância regulada, sendo que, no que tange ao funcionamento e organização dos afazeres do Estado-Juiz, prepondera o dispositivo regimental.

\footnotetext{
${ }^{8}$ CRETELLA JÚNIOR, José. Comentários à Constituição Brasileira de 1988. Rio de Janeiro: Forense Universitária, 1997.

${ }^{9}$ HC 143.333, Rel. Min. Edson Fachin, j. 12-4-2018, P, DJE de 21-3-2019.
} 
Revista Eletrônica de Direito Processual - REDP.

Rio de Janeiro. Ano 15. Volume 22. Número 2. Maio a Agosto de 2021

Periódico Quadrimestral da Pós-Graduação Stricto Sensu em Direito Processual da UERJ

Patrono: José Carlos Barbosa Moreira (in mem.). ISSN 1982-7636. pp. 22-44 www.redp.uerj.br

Aquilo que está contido no regimento interno dos tribunais estaduais como sendo de sua competência privativa, estando tais temas contidos no artigo 96 da Constituição Federal, não poderá ser delegado e nem sequer ter sua convalidação posterior se não atender a este regramento. Da mesma forma, os demais tribunais devem obedecer de maneira vinculada tudo aquilo que for pronunciado em plenário pelo Supremo Tribunal Federal.

Por exemplo, quanto à determinação da competência privativa para propositura de projeto de lei que trate dos teores constantes no artigo 96, II, "b" da Carta Magna, os Tribunais Estaduais devem obedecer as respectivas normas legislativas (Constituição Federal, Constituição do Estado, Lei de Organização Judiciária e respectivo Regimento Interno) sob pena de o processo legislativo sofrer vício formal de iniciativa, vício esse que é incurável, de forma a invalidá-lo por completo.

Ora, se é dada a independência dos Poderes, sendo possível o Poder Judiciário estabelecer e criar sua lei interna, deve-se entender que, frente a faculdade e principalmente da carência de controle, devem ser observados regramentos colocados pelos demais Poderes, entre eles a obediência aos regramentos de processo legal e às garantias processuais das partes envolvidas.

As regras processuais dizem respeito à disciplina processual, da maneira em que se dará a vinculação do que almeja, visando à solução do conflito de interesses e possuem teor claramente vinculado para o que ocorre em Juízo, ou seja, o momento em que o litígio abarca no Poder forense ou, quando for o caso, a ocasião em se celebra o trato arbitral, sob os traços de lide.

Embora como já demonstrado a doutrina majoritária e jurisprudência dominante entendam que os tribunais possuem autonomia para elaborarem seus respectivos regimentos internos além de agasalharem o conceito de que tais regimentos se tratam de lei em sentido material, as normas regimentais não são classificadas na mesma hierarquia das normas de processo. Dessa forma, se as regras processuais forem desrespeitadas, as normas regimentais perdem toda sua efetividade.

Neste sentido, explicou o professor José Frederico Marques ${ }^{10}$ :

O regimento é lei em sentido material, embora não o seja em sentido formal. Na hierarquia das fontes normativa do Direito, ele se situa abaixo da lei, porquanto deve dar-lhe execução (...). Sempre que a norma jurídica, contida em lei formal, apresente regras vagas, imprecisas,

\footnotetext{
${ }^{10}$ MARQUES, José Frederico. Instituições de Direito Processual Civil. Vol. 1. Campinas: Millenium, 2000, p. 186
} 
Revista Eletrônica de Direito Processual - REDP.

Rio de Janeiro. Ano 15. Volume 22. Número 2. Maio a Agosto de 2021

Periódico Quadrimestral da Pós-Graduação Stricto Sensu em Direito Processual da UERJ

Patrono: José Carlos Barbosa Moreira (in mem.). ISSN 1982-7636. pp. 22-44

www.redp.uerj.br

estabelecendo apenas princípios gerais, omitindo detalhes necessários à efetiva observância, cumpre à lei material, contida em preceito regulamentar (como o regimento), desenvolvê-la com novas normas, dela extraindo-se, assim, sentidos e consequências nela implícitos, ou os detalhes para sua fiel execução. Em tal caso, o conteúdo exato da norma superior (lei) determina-se através da norma inferior (regulamento).

Conforme se depreende do trecho acima, a autoridade das normas de organização forense deve ser limitada à própria administração do Poder Judiciário, com designações de seus membros e de seus servidores, em sentido meramente funcional, de maneira que não adentre conteúdos de feitio processual.

O regimento interno de tribunal, embora a denominação de "interno" também seja dirigida aqueles que estão de fora de seu funcionamento, como as partes, seus representantes legais e ao público externo em geral, o devido processo legal deve ser estritamente cumprido, em observância ao regramento positivado Constitucional.

O Supremo Tribunal Federal consolidou entendimento na direção de que os regramentos, na ocasião de julgar, devem ser aquelas declinadas no regimento, não tendo a faculdade de interferência dos outros Poderes. Além disso, além de ser compreendido como lei material, é equiparado às leis de natureza processual, de forma que a prevalência de uma perante a outra dependerá da matéria a ser regida e regulada.

Assinalou o doutrinador José Frederico Marques: ${ }^{11}$

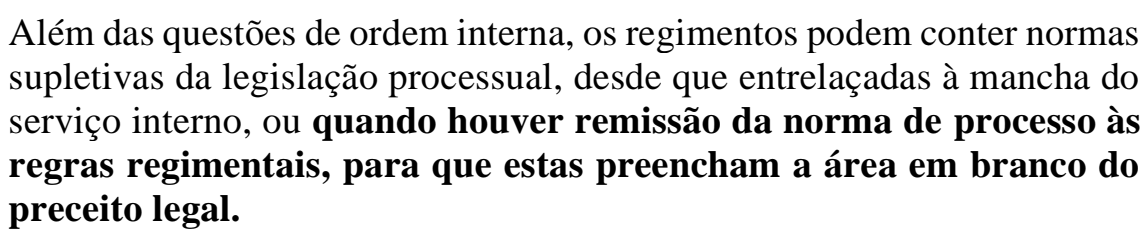

Convém salientar que há matérias tratadas no CPC que nitidamente poderiam estar inseridas apenas nos regimentos internos dos tribunais. Porém, isto não se trata de afronta à Constituição Federal, afinal não se configurarão prejuízos às partes que estiverem presentes em lides, pelo contrário, já que estas terão garantias mais fortes. Assim, conclui-se que os regimentos internos dos tribunais são detentores de autonomia e liberdade para regerem os trabalhos internos das casas judiciárias. Porém, estes regimentos possuem o dever de respeitar as restrições contidas na Constituição Federal em seu artigo 96, inciso I, alínea "a", afinal os atos normativos e as garantias processuais dadas às partes devem ser observados.

\footnotetext{
${ }^{11}$ MARQUES, José Frederico. Instituições de Direito Processual Civil. Vol. 1. Campinas: Millenium, 2000
} 
Revista Eletrônica de Direito Processual - REDP.

Rio de Janeiro. Ano 15. Volume 22. Número 2. Maio a Agosto de 2021

Periódico Quadrimestral da Pós-Graduação Stricto Sensu em Direito Processual da UERJ

Patrono: José Carlos Barbosa Moreira (in mem.). ISSN 1982-7636. pp. 22-44

www.redp.uerj.br

Desta forma, mesmo que há de ser denotada a autonomia de cada um dos Poderes do Estado, de forma que devem interferir minimamente entre um e outro em seus funcionamentos, existem limitações que devem ser obedecidas.

\section{O artigo 927 do Código de Processo Civil e seus elementos vinculantes}

Anteriormente à vigência do $\mathrm{CPC} / 15$, todas as situações de decisão com força vinculante erga omnes (em sentido estrito) diziam respeito aos instrumentos previstos na Constituição Federal relativos ao controle concentrado de constitucionalidade exercido pelo STF. O NCPC explicitou a necessidade de uniformização da jurisprudência e de conservação de sua estabilidade, integridade e coerência (art. 926), bem como reafirmou também a imprescindibilidade de respeito à jurisprudência (art. 927). Em contrapartida, o novo Codex amplificou as hipóteses de força vinculante em sentido estrito. Tal eficácia vinculante é também conferida às decisões emanadas nos procedimentos de recursos especiais e de recursos extraordinários repetitivos e nos incidentes de resolução de demandas repetitivas e de assunção de competência. ${ }^{12}$

Neste ponto, sugere-se o questionamento a respeito de qual seria a interpretação de sentido adequada ao vocábulo "observarão" que está presente no caput do artigo 927 do CPC, ou seja, se o dispositivo cria dever obrigacional aos juízes e tribunais, de forma que as decisões, enunciados, acórdãos e orientações ali discriminados tenham força vinculante ou se apenas impõe ao órgão jurisdicional a obrigação de levar em conta em seus julgamentos o que foi disposto nas decisões, enunciados, acórdãos e orientações ali descritas, tendo estes últimos, então, mera característica persuasiva para a formação da convicção do julgador.

Neste ponto, é majoritária na doutrina consultada a interpretação de que o termo “observarão" contido no artigo 927, caput, do CPC 2015 possui o sentido de que as decisões, enunciados, acórdãos e orientações discriminados nos incisos do mesmo artigo possuem eficácia vinculante, ou seja, de adoção obrigatória de seus teores.

Por fim, é necessário dizer que o fato de as decisões, enunciados, acórdãos e orientações contidas nos incisos do artigo 927 do CPC possuírem caráter impositivo, isso

12 TALAMINI, Eduardo. $O$ que são os "precedentes vinculantes" no CPC/15. Disponível em: $\langle$ http://www.conjur.com.br/2016-ago-18/senso-incomum-isto-sistema-sic-precedentes-cpc〉. Acesso em: 19.08.2020 
Revista Eletrônica de Direito Processual - REDP.

Rio de Janeiro. Ano 15. Volume 22. Número 2. Maio a Agosto de 2021

Periódico Quadrimestral da Pós-Graduação Stricto Sensu em Direito Processual da UERJ

Patrono: José Carlos Barbosa Moreira (in mem.). ISSN 1982-7636. pp. 22-44

www.redp.uerj.br

não significa que não há mais diferenciação entre as súmulas vinculantes previstas no artigo 103-A da Constituição Federal e as do inciso IV do artigo 927 do CPC, afinal as primeiras são também de observância obrigatória em relação aos demais órgãos da administração pública direta e indireta, nos âmbitos federal, estadual e municipal. Já as súmulas do inciso IV do artigo 927 do CPC não possuem eficácia vinculante no âmbito administrativo.

Dos incisos contidos no artigo 927 do CPC, alguns deles se sobressaem por terem sido criados com o novo Codex, já outros já existiam no Código de Processo Civil de 1973, embora ainda não contivessem de forma expressa a eficácia vinculante. Necessário dizer que também já havia incisos que possuíam eficácia vinculante.

Os dois primeiros incisos do artigo 927 só vieram a reforçar o que já estava previsto nos artigos 102, § $2^{\circ}$ e 103-A, caput, da Constituição Federal, afinal trazem o comando legal de que os juízes e tribunais devem observar o que já foi julgado pelo Supremo Tribunal no exercício do controle concentrado de constitucionalidade, assim como os enunciados de súmula vinculante editados pelo Supremo. Dessa forma, aqui não temos grande novidade em nosso ordenamento jurídico. Entretanto, no inciso III do artigo 927 do CPC já presenciamos algo inovador em relação ao antigo código, afinal tal artigo determina que os juízes e tribunais devem observar em seus julgados os acórdãos em incidente de assunção de competência ou de resolução de demandas repetitivas.

Outros dispositivos legais também reafirmam o poder vinculante dos acórdãos em incidente de assunção de competência ou de resolução de demandas repetitivas: o artigo 947, $\S 3^{\circ}$ do CPC afirma que "o acórdão proferido em assunção de competência vinculará todos os juízes e órgãos fracionários, exceto se houver revisão de tese” e o artigo 985 do CPC diz que julgado o incidente de resolução de demandas repetitivas, sua tese jurídica será aplicada " a todos os processos individuais ou coletivos que versem sobre idêntica questão de direito e que tramitem na área de jurisdição do respectivo tribunal, inclusive àqueles que tramitem nos juizados especiais do respectivo Estado ou região" (inciso I) e também "aos casos futuros que versem idêntica questão de direito e que venham a tramitar no território de competência do tribunal, salvo revisão" (inciso II). ${ }^{13}$

${ }_{13}^{13}$ NEVES, Daniel Amorim Assumpção. Novo Código de Processo Civil - Lei 13.105/2015 - Inovações, alterações e supressões. Rio de Janeiro: Forense; São Paulo: Método, 2015. 
Revista Eletrônica de Direito Processual - REDP.

Rio de Janeiro. Ano 15. Volume 22. Número 2. Maio a Agosto de 2021

Periódico Quadrimestral da Pós-Graduação Stricto Sensu em Direito Processual da UERJ

Patrono: José Carlos Barbosa Moreira (in mem.). ISSN 1982-7636. pp. 22-44

www.redp.uerj.br

Aqui é importante fazer presente o que está contido no artigo 987, $\S 2^{\circ}$ : sendo

cabível recurso extraordinário ou especial do julgamento do mérito do incidente de resolução de demandas repetitivas, apreciado o mérito o recurso, a tese jurídica adotada pelo Supremo Tribunal Federal ou pelo Superior Tribunal de Justiça será aplicada em todo o território nacional a todos os processos individuais ou coletivos que versem sobre idêntica questão de direito.

O artigo 927, inciso III do CPC 2015 também afirma que os juízes e tribunais observarão os acórdãos em julgamento de recursos extraordinário e especial repetitivos. Neste ponto, observa-se que a sistemática é a mesma do antigo CPC de 1973, embora o artigo 927 do CPC 2015 não tenha artigo em correspondência no CPC 1973. O artigo 927, inciso III, neste ponto, fortaleceu a eficácia ultra partes e vinculante destes julgamentos, da mesma forma que os artigos 1039 e 1040 do CPC 2015, trazendo regras no âmbito do julgamento dos recursos extraordinário e especial repetitivos, determinando que os tribunais de $2^{\circ}$ grau e aos tribunais superiores deverão aplicar a tese lá veiculada ou se retratarem de decisões proferidas em sentido diverso dessas mesmas teses.

Neste ponto, convém reproduzir o artigo 988, IV do CPC, no sentido de que:

Caberá reclamação da parte interessada ou do Ministério Público para: IV - garantir a observância de acórdão proferido em julgamento de incidente de resolução de demandas repetitivas ou de incidente de assunção de competência;

O parágrafo $1^{\circ}$ do referido artigo afirma que a reclamação pode ser proposta perante qualquer tribunal que e seu julgamento compete ao órgão jurisdicional cuja competência se busca preservar ou cuja autoridade se pretenda garantir.

Já a leitura atenta do parágrafo $5^{\circ}$, inciso II do mesmo artigo faz crer que a reclamação também é admitida para garantir a observância de acórdão de recurso extraordinário com repercussão geral reconhecida ou de acórdão proferido em julgamento de recursos extraordinário ou especial repetitivos, porém desde que esgotadas as instâncias ordinárias.

Segundo o artigo 927, inciso IV do CPC, os juízes e os tribunais também observarão os enunciados das súmulas do Supremo Tribunal Federal em matéria constitucional e do Superior Tribunal de Justiça em matéria infraconstitucional. Neste ponto, questiona-se se com a vigência deste inciso haveria agora diferenciação entre súmulas editadas pelo Supremo Tribunal Federal e pelo Superior Tribunal de Justiça e as súmulas vinculantes. 
Revista Eletrônica de Direito Processual - REDP.

Rio de Janeiro. Ano 15. Volume 22. Número 2. Maio a Agosto de 2021

Periódico Quadrimestral da Pós-Graduação Stricto Sensu em Direito Processual da UERJ

Patrono: José Carlos Barbosa Moreira (in mem.). ISSN 1982-7636. pp. 22-44

www.redp.uerj.br

Assim, após a publicação da Lei n ${ }^{\circ}$ 13.256/2016, que alterou trechos do CPC 2015 para disciplinar o processo e o julgamento do recurso extraordinário e do recurso especial, passou a ser indiscutível que a respeito do tema, a reclamação é somente admitida em casos de desrespeito ao disposto em súmula vinculante, conforme faz crer a interpretação do reformado artigo 988, inciso III do CPC 2015: "Caberá reclamação da parte interessada ou do Ministério Público para: III - garantir a observância de enunciado de súmula vinculante $e$ de decisão do Supremo Tribunal Federal em controle concentrado de constitucionalidade".

O artigo 927, inciso IV do CPC, também faz crer que as súmulas editadas pelo STF, em matéria infraconstitucional, não podem ter força vinculante, desobrigando os juízes e tribunais de observá-las, reforçando o conceito de que o Superior Tribunal de Justiça é quem dá a palavra final sobre a interpretação e a utilização das normas infraconstitucionais em nosso ordenamento jurídico. ${ }^{14}$

O doutrinador Neves também apresenta a controvérsia doutrinária sobre a constitucionalidade da eficácia vinculante das súmulas apresentadas pelo artigo 927, IV do CPC, afinal via de regra tal caráter vinculante seria somente advindo de comando constitucional, como é o caso das decisões judiciais proferidas no exercício do controle concentrado de constitucionalidade e das súmulas vinculantes do STF. Da mesma forma, há forte discussão se a eficácia vinculante dos precedentes gerados no julgamento dos incidentes de assunção de competência ou de resolução de demandas repetitivas prevista no artigo 927, III do CPC não é consequência da invasão do Poder Judiciário nas atribuições do Poder Legislativo, gerando vinculações sem força constitucional a preceitos genéricos impostos pelo Poder Judiciário, afinal estes passam a ter feições de comando legal.

Diante destas discussões de caráter constitucionalista, apenas com a utilização destes mecanismos legais é que descobriremos qual será o seu verdadeiro alcance e de que forma os tribunais irão recepcioná-los, embora haja a certeza de que, para todos os efeitos, se o dispositivo contido no Código de Processo Civil não for impugnado pelas vias adequadas perante o Supremo Tribunal Federal e se não sobrevier declaração de sua inconstitucionalidade, não há outro entendimento a não ser o de sua total aplicabilidade e vigência.

${ }^{14}$ NEVES, Daniel Amorim Assumpção. Novo Código de Processo Civil - Lei 13.105/2015 - Inovações, alterações e supressões. Rio de Janeiro: Forense; São Paulo: Método, 2015. 
Revista Eletrônica de Direito Processual - REDP.

Rio de Janeiro. Ano 15. Volume 22. Número 2. Maio a Agosto de 2021

Periódico Quadrimestral da Pós-Graduação Stricto Sensu em Direito Processual da UERJ

Patrono: José Carlos Barbosa Moreira (in mem.). ISSN 1982-7636. pp. 22-44

www.redp.uerj.br

Aqui cabe observar que o inciso V do artigo 927 do Código de Processo Civil de

2015 dispõe que os juízes e os tribunais deverão observar a orientação do plenário ou do órgão especial aos quais estiverem vinculados. Tal inciso reforça a ideia de um sistema íntegro e coerente em que o intérprete tem o dever de decidir o novo caso colocado aos seus olhos, como componente de um profundo empreendimento em sequência do qual os capítulos pretéritos (julgados decorridos e entendimentos doutrinários já firmados) devem ser levados lembrados para que se redija um novo capítulo, como continuação, que o siga ou o sobrepuja com coesão e harmonia. ${ }^{15}$

\section{O artigo 928 do Código de Processo Civil e o julgamento de casos repetitivos}

Da leitura do artigo 928 do Código de Processo Civil, notamos que são entendidos como julgamentos de casos repetitivos o incidente de resolução de demandas repetitivas (IRDR) e os recursos especial e extraordinário repetitivos. Os precedentes que foram fixados nos mecanismos citados buscam desafogar o sistema judiciário brasileiro e têm a intenção de conferir maior celeridade processual às demandas, conforme dita o princípio da razoável duração do processo. Assim sendo, os conteúdos definidos nos julgamentos de casos repetitivos devem servir como base para outros temas similares.

Em relação ao incidente de resolução de demandas repetitivas, foi definido pelo enunciado $\mathrm{n}^{\mathrm{o}} 88$ do Fórum Permanente de Processualistas Civis (FPPC) que não existe restrição de matérias de direito que o possam ensejar. Dessa forma, não pode haver interpretação legal no sentido de limitar a aplicação deste tipo de incidente: "Não existe limitação de matérias de direito passíveis de gerar a instauração do incidente de resolução de demandas repetitivas e, por isso, não é admissível qualquer interpretação que, por tal fundamento, restrinja seu cabimento”. Já o enunciado no 327 do FPPC definiu que os precedentes vinculantes podem ter por objeto questão de direito material ou processual: " $O s$ precedentes vinculantes podem ter por objeto questão de direito material ou processual".

Conforme rege o parágrafo único deste dispositivo, ao admitir que o julgamento de casos repetitivos nas três formas indicadas pelo artigo verse sobre questões de ordem

15 THEODORO JÚNIOR, Humberto. Novo CPC - Fundamentos e Sistematização. Rio de Janeiro: Forense, 2015. 
Revista Eletrônica de Direito Processual - REDP.

Rio de Janeiro. Ano 15. Volume 22. Número 2. Maio a Agosto de 2021

Periódico Quadrimestral da Pós-Graduação Stricto Sensu em Direito Processual da UERJ

Patrono: José Carlos Barbosa Moreira (in mem.). ISSN 1982-7636. pp. 22-44

www.redp.uerj.br

material ou de ordem processual, buscou-se eliminar discussões sobre o alcance de tais julgamentos. Os precedentes fixados nos casos repetitivos têm como finalidade desafogar o sistema judiciário nacional e pretendem conferir maior celeridade aos autos judiciais, em primazia ao princípio da razoável duração do processo. Dessa forma, os temas tratados nos incidentes repetitivos devem servir de parâmetro para outras questões semelhantes. ${ }^{16}$

\section{Os recursos extraordinário e especial repetitivos}

O Código de Processo Civil possui previsão a respeito do julgamento por "amostragem" de recursos extraordinários e especiais, toda vez que for notada a interposição de variedade numérica desses recursos relativos a uma matéria específica. O principal intuito deste julgamento de recursos extraordinários e especiais repetitivos é extinguir divergências e minimizar a quantidade de recursos levados ao Supremo Tribunal Federal e ao Superior Tribunal de Justiça.

O julgamento de recursos extraordinários e especiais repetitivos é um instrumento que possui como objetivo a gênese de precedentes judiciais vinculantes, a serem utilizados como referências decisórias que deverão de ser seguidos e observados pelos institutos judiciais brasileiros na ocasião da apreciação de casos em que discutem as semelhantes matérias de direito já fixadas, e perante situações de fato equivalentes. Outrossim, trata-se de um método que objetiva permitir a administração das chamadas "causas repetitivas", evitando que o STF e o STJ fiquem inundados de causas a julgar em decorrência da interposição de excessiva quantidade de recursos tratando sobre os mesmos conteúdos e objetos de direito, afinal tais tribunais superiores além de possuírem competência sobre todo o vasto território nacional, também são compostos por pequena quantidade de magistrados, sendo apenas onze no STD e trinta e três no STJ. ${ }^{17}$

Não há qualquer cabimento em compelir o Pretório Excelso ou o Superior Tribunal de Justiça a anunciar várias e várias vezes a mesma elucidação de determinado tema ou questão. Sendo tais tribunais superiores cortes de formação de interpretação e de precedentes, o total estudo de questão específica em uma única ocasião é potencialmente

\footnotetext{
${ }^{16}$ MARINONI, Luiz Guilherme. Novo Código de Processo Civil Comentado. $1^{\mathrm{a}}$ ed. São Paulo: Editora Revista dos Tribunais, 2017.

${ }^{17}$ CÂMARA, Alexandre Freitas. São Paulo: Atlas, 2015.
} 
Revista Eletrônica de Direito Processual - REDP.

Rio de Janeiro. Ano 15. Volume 22. Número 2. Maio a Agosto de 2021

Periódico Quadrimestral da Pós-Graduação Stricto Sensu em Direito Processual da UERJ

Patrono: José Carlos Barbosa Moreira (in mem.). ISSN 1982-7636. pp. 22-44

www.redp.uerj.br

suficiente para que estes tribunais superiores tenham por cumpridas suas funções simbólicas.

E é por esse motivo que o método de julgamento em bloco coaduna com perfeição com a nova feição dos recursos extraordinário e especial. ${ }^{18}$

Ao se constatar a interposição de recursos extraordinários ou especiais baseados em semelhante questão de direito de maneira repetitiva, o presidente ou vice-presidente dos tribunais de origem procederão à escolha de dois ou mais recursos que representem a controvérsia, encaminhando-os, conforme o caso, ao Superior Tribunal de Justiça ou ao Supremo Tribunal Federal. No mesmo ato será ordenada a suspensão de todos os demais recursos que não foram selecionados como retratos da controvérsia, conforme dita o parágrafo $1^{\circ}$ do artigo 1.036. Não ocorre a suspensão das ações e dos recursos de maneira automática, sendo necessário despacho do juiz da causa ou do relator do recurso, já que é necessária a verificação do enquadramento do caso concreto ao conjunto dos processos suspensos. As partes necessitam ser intimadas da decisão de suspensão, sendo esta irrecorrível. Entretanto, é cabível a impetração de mandado de segurança contra ela. ${ }^{19}$

A suspensão compreende a totalidade das ações em trâmite e que até o momento não tiverem recebido solução definitiva. Porém, não há impedimento ao ajuizamento de novas demandas, sob a ressalva de que elas ficarão suspensas no juízo de primeiro grau. As partes serão intimadas da suspensão de seus processos, ocasião em que será possível o requerimento ao juiz ou a tribunal onde tramitarem sobre o prosseguimento da ação individual, sob a ressalva de seja comprovada a diferença entre a questão a ser decidida no processo em voga e aquela a ser julgada pelo STF ou STJ.

Nos termos do artigo 1.036, $\S 3^{\circ}$ do CPC é cabível agravo dirigido ao tribunal ad quem contra a decisão que indefere o requerimento previsto no $\S 2^{\circ}$ do mesmo artigo e, como consequência, afirma a tempestividade do recurso sobrestado. Outra situação que possibilita o requerimento ocorre quando a parte entender que o caso de seu processo ou recurso é diferente, tendo sido, portanto, indevidamente suspenso. Pedir-se-á então o prosseguimento e será intimada a parte contrária a fim de que no prazo de cinco dias se manifeste sobre o requerimento.

\footnotetext{
${ }^{18}$ MARINONI, Luiz Guilherme. O Novo Processo Civil. $1^{\text {a }}$ ed. São Paulo: Editora Revista dos Tribunais, 2015.

${ }^{19}$ TESHEINER, José Maria. Novo Código de Processo Civil Anotado. Porto Alegre: OAB/RS, 2015.
} 
Revista Eletrônica de Direito Processual - REDP.

Rio de Janeiro. Ano 15. Volume 22. Número 2. Maio a Agosto de 2021

Periódico Quadrimestral da Pós-Graduação Stricto Sensu em Direito Processual da UERJ

Patrono: José Carlos Barbosa Moreira (in mem.). ISSN 1982-7636. pp. 22-44

www.redp.uerj.br

Nos ternos do $\S 4^{\circ}$ do supracitado dispositivo, a seleção dos tribunais de origem não vincula o STF e o STJ, pois estes têm a liberdade de separar outros recursos que servirão como modelo de julgamento, em conformidade com o que for definido como entendimento da corte. Nos tribunais superiores serão verificados os requisitos contidos no $\S 6^{\circ}$ do referido artigo: os recursos selecionados devem ser admissíveis e conter abrangente arguição e demonstração a respeito da matéria controversa, permitindo a discussão do seu mérito. Estando presentes os requisitos, será prolatada a decisão de afetação sobre o tema. ${ }^{20}$

No caso de a decisão negar a afetação, o tribunal de origem será informado, para que proceda a revogação da decisão que suspendeu os processos que lá ficaram pendentes de julgamento, nos termos do artigo 1.037, §1 ${ }^{\circ}$, do CPC. É essencial que a decisão de afetação delimite de forma clara a questão a ser julgada e que o Ministro Relator também determine a suspensão de todos os processos pendentes, sejam eles individuais ou coletivos, que tratem sobre a questão e que transcorram em território brasileiro (art. 1.037, II, do CPC). Tal sobrestamento de processos tem como finalidade atingir a celeridade, a segurança jurídica e celebrar o trato isonômico.

O processualista Theodoro Júnior ${ }^{21}$ assevera que o tratamento dado aos repetitivos está inserido em “(...) um grande sistema processual voltado, precipuamente, para uniformizar e tornar previsível a interpretação e aplicação da lei, com vistas à segurança jurídica”. Destaque-se que a decisão emitida em sede de recurso repetitivo emanará eficácia vinculante perante todos os processos em curso no Brasil, sendo cabível reclamação contra o decisum que não a observar, desde que não restem mais instâncias recursais ordinárias, de acordo com o art. 988, $\S 5^{\circ}$, II, do CPC.

De resto, há que se falar que os julgamentos dos recursos afetados têm preferência sobre os demais feitos, salvo aqueles que envolvam réu preso e pedidos de habeas corpus. De qualquer forma, o recurso repetitivo deverá ser julgado no prazo de um ano (art. 1.037, $\S 4^{\circ}$, do CPC). Tesheiner ${ }^{22}$ discorreu que a eficácia da ordem de suspensão dos processos em todo o país cessa após um ano da publicação da respectiva decisão, porém pode ser novamente determinada por decisão de outro relator, possibilitando assim, na prática, a hipótese de suspensão por prazo indeterminado.

\footnotetext{
${ }^{20}$ THEODORO JÚNIOR, Humberto. Curso de Direito Processual Civil, Vol. I. Rio de Janeiro: Forense, 2016.

${ }^{21}$ THEODORO JÚNIOR, Humberto. Curso de Direito Processual Civil, Vol. III. Rio de Janeiro: Forense, 2016, a, p. 1411

22 TESHEINER, José Maria. Novo Código de Processo Civil Anotado. Porto Alegre: OAB/RS, 2015.
} 


\section{A Teoria dos Precedentes, a superação (overruling) e a distinção (distinguishing)}

A intitulada "Teoria dos Precedentes" tem origem no sistema de common law norteamericano. Tal teoria reflete o costume de raciocínio em que o julgador, empregando uma séria de princípios e normas, harmoniza determinado entendimento jurídico relativo a uma circunstância concreta. Em outras palavras, traduz-se pela atitude de criação do juiz ocorrida em determinada decisão, que, nas futuras a serem proferidas, pauta a obrigação de seguir seu modelo, organização e uniformidade. Ou seja, por meio desta ideia o direito é fabricado ou lapidado pelos julgadores, de forma que um decisum a ser emitido a um caso se sujeita às decisões proferidas em casos pretéritos e interfere no direito a ser empregue em situações futuras. Assim sendo, pode-se falar que a Teoria dos Precedentes é baseada nos princípios da isonomia, coerência e segurança jurídica e possui o intuito de impedir o beneficiamento pessoal. $^{23}$

Apesar de essa teoria ter nascido no sistema de common law norte-americano, ela não é exclusiva deste sistema e, embora o Brasil não o adote, mas sim o chamado civil law, em determinados momentos nosso ordenamento jurídico adota alguns tópicos do common law, a exemplo da referida teoria. Outros exemplos de incorporação e conceitos característicos do common law pelo ordenamento jurídico brasileiro, mesmo que de forma tímida, podem ser observados quando são considerados pelos julgadores os costumes nas situações em que há omissão legal ou quando se admite o uso da analogia ou dos princípios gerais de direito ao se julgar perante ausência legislativa.

Superar um precedente significa removê-lo do ordenamento jurídico como direito vigente, inserindo algo moderno e fresco em seu lugar. No momento em que um precedente é extinto e revogado, o órgão julgador está rejeitando segui-lo e declarando que, em que pese os elementos da situação concreta em análise serem materialmente similares aos fatos do caso usado como exemplo (paradigma), uma inovadora determinação há de empregada no

\footnotetext{
${ }^{23}$ MANSUR, Sâmea Luz. A Teoria dos Precedentes e os Institutos do "Overrunling" e do "Distinguishing" Disponível em: 〈https://samealuz.jusbrasil.com.br/artigos/383859816/a-teoria-dos-precedentes-e-osinstitutos-do-overrunling-e-do-distinguishing $>$. Acesso em: 21.08.2020.
} 
Revista Eletrônica de Direito Processual - REDP.

Rio de Janeiro. Ano 15. Volume 22. Número 2. Maio a Agosto de 2021

Periódico Quadrimestral da Pós-Graduação Stricto Sensu em Direito Processual da UERJ

Patrono: José Carlos Barbosa Moreira (in mem.). ISSN 1982-7636. pp. 22-44

www.redp.uerj.br

decisum a ser proferido. Entretanto, tal revisão apenas poderá ser efetuada pelo próprio órgão que sedimentou a tese, sob o risco de perda da força vinculante. ${ }^{24}$

A superação de um precedente normativo também é chamada de overruling e pode ocorrer de forma expressa ou tácita. De acordo com o professor Marinoni (2015) tal instituto é empregado no Brasil de forma imperfeita porque inexistem regras concretas a serem atentadas na alteração de um precedente normativo brasileiro, como ocorre nos Estados Unidos, que atende um dos seguintes parâmetros: a) alteração no entendimento geral acerca do direito; b) modificação dos valores sociais; c) desenvolvimento da tecnologia; d) efeitos esperados que não foram efetivamente obtidos; e) evidente desacerto (erro crasso).

Em nosso ordenamento jurídico pátrio não há tais exigências a serem cumpridas, de forma que os precedentes obrigatórios geralmente são superados, por exemplo, pela alteração da convicção pessoal do juiz ou até mesmo pela modificação da composição do colegiado de determinado tribunal, causando aos jurisdicionados inevitável insegurança jurídica. Determinadas vezes os tribunais não realizam o overruling, mas aplicam signaling, ou seja, emite sinais de que a jurisprudência será modificada ou acompanhará uma determinada orientação. ${ }^{25}$

De outra sorte, a distinção (distinguishing) realiza-se quando o caso concreto $s u b$ judice exibe especificidades que não autorizam adotar devidamente a jurisprudência do tribunal harmonizada em um precedente normativo. É, assim, a não aplicação de um precedente normativo pelo magistrado, pelo motivo de o caso concreto conter certas particularidades que permitem ao julgador excepcionar a tese definida pela jurisprudência, de modo a limitar sua aplicação ou rechaçá-la completamente. ${ }^{26}$

\section{Conclusão}

Com a análise feita no decorrer do presente estudo, foi observado a importância da diferença dos precedentes do sistema do civil law brasileiro em relação aos precedentes dos

\footnotetext{
${ }^{24}$ CASTRO, Guilherme Fortes Monteiro e GONÇALVES, Eduardo da Silva. A aplicação da common law no Brasil: diferenças e afinidades. Disponível em: <https://ambitojuridico.com.br/cadernos/direitoconstitucional/a-aplicacao-da-common-law-no-brasil-diferencas-e-afinidades/>. Acesso em: 14.08.2010.

${ }^{25}$ MARINONI, Luiz Guilherme. Novo Curso de Processo Civil, volume 2. São Paulo: Revista dos Tribunais, 2015.

${ }^{26}$ DIDIER JÚNIOR, Fredie. Curso de Direito Processual Civil. Vol. 2. 10ª ed. Salvador: JusPodivm, 2015.
} 
Revista Eletrônica de Direito Processual - REDP.

Rio de Janeiro. Ano 15. Volume 22. Número 2. Maio a Agosto de 2021

Periódico Quadrimestral da Pós-Graduação Stricto Sensu em Direito Processual da UERJ

Patrono: José Carlos Barbosa Moreira (in mem.). ISSN 1982-7636. pp. 22-44

www.redp.uerj.br

países com sistema do common law, como os Estados Unidos e a Inglaterra. Com isso, observamos que apesar do ordenamento jurídico brasileiro ser típico do civil law, adicionamos em nosso sistema processual um modelo de precedentes peculiar e diverso daquele originado do direito britânico, uma vez que o suporte fático da norma do civil law se mostra amplo e abstrato em relação aos elementos de fato do precedente da commom law. Neste último sistema, os fatos da análise de casos integram a ratio decidendi da norma, não havendo uma diferença entre fato e norma.

O sistema de precedentes elencados nos dispositivos do novo CPC tem por fim racionalizar a fundamentação da decisão judicial com o fim de reduzir a discricionariedade judicial e trazer previsibilidade do direito para os jurisdicionados. Com a uniformização jurisprudencial, os tribunais aplicam seu entendimento prevalecente a uma diversidade de casos similares, o que antes eram resolvidos a mercê da compreensão de cada julgador. Assim, o consenso dos juízes que constituem um tribunal é algo inerente à formação dos precedentes, da uniformidade jurisdicional e da construção de súmulas vinculantes.

O conceito de precedente possui diversas acepções nas muitas doutrinas, porém o novo Código de Processo Civil, ao trazer tal instituto, tem o objetivo de respeitar a decisão da maioria do tribunal (colegiado) e impor sua obrigatoriedade na aplicação na ratio decidendi dos tribunais inferiores diante de casos análogos. Segue o conceito de precedente definido por Georges Abboud e Lênio Streck: ${ }^{27}$

O precedente é uma decisão de um Tribunal com aptidão a ser reproduzidaseguida pelos tribunais inferiores, entretanto, sua condição de precedente dependerá de ele ser efetivamente seguido na resolução de casos análogossimilares. Ou seja, não há uma distinção estrutural entre uma decisão isolada e as demais que lhe devem "obediência hermenêutica". Há, sim, uma diferença qualitativa, que sempre exsurgirá a partir da applicattio.

O sistema de precedentes apresentado pelo CPC 2015 guarda a exigência de, através da efetividade, promover a segurança jurídica e a isonomia na atuação dos julgadores como consta, por exemplo, no enunciado 87 do Fórum Permanente de Processualistas Civis (FPPC):

"A instauração do incidente de resolução de demandas repetitivas não pressupõe a existência de grande quantidade de processos versando sobre a mesma questão, mas preponderantemente o risco de quebra da isonomia e de ofensa à segurança jurídica".

${ }^{27}$ STRECK, Lenio Luiz; ABBOUD, Georges. O que é isto: o precedente judicial e as súmulas vinculantes? Porto Alegre: Livraria do Advogado, 2013, pp. $42 / 43$ 
O recente ordenamento jurídico processual veio acrescentar mudanças na fundamentação da decisão jurídica conforme seu artigo 489, §1 ${ }^{\circ}$, incisos V e VI em que torna obrigatória a vinculação da ratio decidendi dos juízes e tribunais inferiores às súmulas, precedentes e jurisprudência dos tribunais superiores, sem deixar de analisar os fundamentos determinantes para sua aplicação.

\section{REFERÊNCIAS}

ABBOUD, Georges. Discricionariedade administrativa e judicial: ato administrativo e decisão judicial. São Paulo: Revista dos Tribunais, 2014

CÂMARA, Alexandre Freitas. O Novo Processo Civil Brasileiro. São Paulo: Atlas, 2015.

CASTRO, Guilherme Fortes Monteiro e GONÇALVES, Eduardo da Silva. A aplicação da common law no Brasil: diferenças e afinidades. Disponível em: $<$ https://ambitojuridico.com.br/cadernos/direito-constitucional/a-aplicacao-dacommon-law-no-brasil-diferencas-e-afinidades/>. Acesso em: 14.08.2010.

CRETELLA JÚNIOR, José. Comentários à Constituição Brasileira de 1988. Rio de Janeiro: Forense Universitária, 1997.

DIDIER JÚNIOR, Fredie. Curso de Direito Processual Civil. Vol. 2. 10 a ed. Salvador: JusPodivm, 2015.

DINAMARCO, Candido Rangel. A reforma do código de processo civil. $4^{\mathrm{a}}$ ed. São Paulo: Malheiros, 2001.

MANSUR, Sâmea Luz. A Teoria dos Precedentes e os Institutos do "Overrunling" e do "Distinguishing" - - Disponível em: $<$ https://samealuz.jusbrasil.com.br/artigos/383859816/a-teoria-dos-precedentes-e-osinstitutos-do-overrunling-e-do-distinguishing>. Acesso em: 21.08.2020.

MARINONI, Luiz Guilherme. Novo Código de Processo Civil Comentado. $1^{\text {a }}$ ed. São Paulo: Editora Revista dos Tribunais, 2017.

MARINONI, Luiz Guilherme. Novo Curso de Processo Civil, volume 2. São Paulo: Revista dos Tribunais, 2015.

MARQUES, José Frederico. Instituições de Direito Processual Civil. Vol. 1. Campinas: Millenium, 2000 
Revista Eletrônica de Direito Processual - REDP.

Rio de Janeiro. Ano 15. Volume 22. Número 2. Maio a Agosto de 2021

Periódico Quadrimestral da Pós-Graduação Stricto Sensu em Direito Processual da UERJ

Patrono: José Carlos Barbosa Moreira (in mem.). ISSN 1982-7636. pp. 22-44

www.redp.uerj.br

NEVES, Daniel Amorim Assumpção. Novo Código de Processo Civil - Lei 13.105/2015 -

Inovações, alterações e supressões. Rio de Janeiro: Forense; São Paulo: Método, 2015.

OLIVEIRA, Celso Marcelo de. Moderno Direito Processual Civil do Brasil e de Portugal. Revista de Doutrina da $4^{a}$ Região, $\mathrm{n}^{\mathrm{o}}$ 10, 2006.

TESHEINER, José Maria. Novo Código de Processo Civil Anotado. Porto Alegre: OAB/RS, 2015.

TALAMINI, Eduardo. O que são os "precedentes vinculantes" no CPC/15. Disponível em: http://www.conjur.com.br/2016-ago-18/senso-incomum-isto-sistema-sicprecedentes-cpc. Acesso em: 19.08.2020.

THEODORO JÚNIOR, Humberto. Novo CPC - Fundamentos e Sistematização. Rio de Janeiro: Forense, 2015.

THEODORO JÚNIOR, Humberto. Curso de Direito Processual Civil, Vol. I. Rio de Janeiro: Forense, 2016.

THEODORO JÚNIOR, Humberto. Curso de Direito Processual Civil, Vol. III. Rio de Janeiro: Forense, 2016.

RAATZ, Igor e SANTANNA, Gustavo da Silva. Elementos da história do processo civil brasileiro: do Código de 1939 ao Código de 1973. Revista Justiça e História, vol. 18. Porto Alegre: 2001.

STRECK, Lenio Luiz; ABBOUD, Georges. O que é isto: o precedente judicial e as súmulas vinculantes? Porto Alegre: Livraria do Advogado, 2013 